\author{
I.A. Khabarov*, V.V. Zhurov, A.N. Zhabayeva, S.M. Adekenov \\ JSC "International Research and Production Holding "Phytochemistry", Karaganda, Kazakhstan \\ (Corresponding author's e-mail: i.khabarov@phyto.kz)
}

\title{
Modeling the extraction process of medicinal raw materials
}

\begin{abstract}
The review considers 26 mathematical models of the process of biologically active substances extraction from medicinal plant raw materials, taking into account factors affecting the extraction process: diffusion coefficient, particle size, layer porosity, extractant feed rate, raw material grinding method, pressure, temperature and duration of extraction, individual characteristics of raw materials (content of the target component) and technological equipment. In general, these models fall into four important groups: empirical models, models based on heat transfer analogies, a shrinking core model, and models based on differential mass balance. Here were described problems that occur in the selection of mathematical models, first of all, associated with the imperfect behavior of the flows of extraction liquids, and the inhomogeneous cross-section of the extraction apparatus. It was shown that first of all the extraction process modeling requires mathematical models to describe the mass transfer inside solid particles. It is also important to take into account the solubility of the target substances when simulating. It is shown that for describing the extraction processes, the optimal models are Naik and Lentz, Esquivel, diffusion, H. Sovová mass transfer, damaged and undamaged cells for calculating the main factors of extraction processes.
\end{abstract}

Keywords: mathematical modeling, mass transfer, diffusion, regression equation, criterion equation, optimization, extraction, plant raw materials

\section{Introduction}

Extraction of medicinal plant raw materials is an integral and important process in phytochemical production.

The theory and practice of the extraction process have been intensively developed in recent years due to the increase in the technical equipment of pharmaceutical production, as well as the solution of problems arising from the consideration of extraction processes in a solid-liquid system.

Analysis of the available information material and literature data indicates that three types of mathematical models can be used to calculate and optimize the process of extracting plant raw materials:

1. Model of differential equations of the process;

2. Model of criterion equations of the process;

3. Model of regression equations.

In this case, the general modeling scheme includes:

1) obtaining and analyzing the model;

2) the model check;

3) introduction to the model of factors that optimize the process, or optimization of the process based on the model;

4) obtaining of a new model;

5) regulation of the production process to obtain optimal yield.

Optimization of the extraction process of plant raw materials requires knowledge of the corresponding parameters of equilibrium and mass transfer, as well as the optimal operating conditions of the extraction apparatus. Mass transfer and solubility parameters can be quantified by applying an adequate mathematical model to laboratory experimental data. Each model includes several simplified assumptions about how the solute is distributed inside the solid body and the mechanisms involved in the kinetics of mass transfer: internal and external resistance to mass transfer, as well as their combination.

Over the years, mathematical models have been developed using three different approaches: (a) empirical modeling; (b) based on simulations similar to heat transfer; and (c) simulations based on differential integration of mass balance. Empirical models are suitable in the case, when there is no information about the mechanisms of mass transfer. However, the need of developing models that take into account mass transfer

\footnotetext{
${ }^{*}$ Corresponding author.
} 
for the mathematical description of the phenomena, occurring during the extraction of plant raw materials, remains relevant.

\section{Main part}

There are several models in the available literature materials to describe the supercritical fluid extraction of plant raw materials in the extraction of oils $[1,2]$. In general, these models can be divided into four important groups: empirical models, models based on heat transfer analogies, a shrinking core model, and models based on differential mass balance. The last class of models has a distinctive physical meaning and covers the coefficients of mass transfer in the liquid and solid phases or only in one phase. They take into account characteristics of the material matrix, such as particle size and layer porosity. There is necessary to determine different coefficients compared to empirical models. However, these models describe the trends and mechanisms carried out by the extraction process [3].

Criterion equations and regression equations obtained by experimental design methods are suitable to describe the extraction processes. The criterion equations interconnect a series of factors: raw material fineness, mass transfer surface, extractant velocity, other hydrodynamic process conditions (pulsations, vibrations), extraction time, concentration of substances in raw materials, coefficients of free and internal diffusion and other factors. The second important direction in modeling is the implementation of research to translate laboratory experiments into factory production conditions. Most criterion equations do not take into account the criteria of geometric similarity and are not suitable for production conditions.

To ensure maximum results by varying process conditions is an important production task in the developing a mathematical production model. Usually the maximum result (most often the yield or the lowest cost of the product) is closely related to some uncontrollable factor, such as the content of substances in the initial raw materials. Therefore, it is advisable to put this value into the model as one of the factors.

Modeling of mass transfer during continuous supercritical extraction by carbon dioxide is necessary for a deep understanding of the mechanisms of the process before it can be used for design, operation, monitoring, process control and optimization. Authors of the work [4], made a mathematical model (1) of the processes of supercritical fluid extraction of Lupinus albus L. seeds, which included system of integrodifferential equations with a core determined by the function of the particle size distribution density:

$$
f(a)=(1-r) \delta(a-1)+r \delta(a-\alpha),
$$

where $r-$ is the part of grains of fine fraction (dust); $\delta$ - is the Dirac delta function.

This model taking into account the polydispersity of the granular layer and the process of mass transfer of components inside the particle through the intercellular channels.

The authors of the work [5] presented the process of supercritical fluid extraction of plant raw materials as extraction with cross-flow and a constant distribution coefficient (2). They derived a dependence that has good agreement with experimental data and it is described by the equation:

$$
y=k / x\{\arcsin [\sin (m x)]\}^{2},
$$

where $k-$ is the equilibrium concentration of biologically active substances in the extractant at the time of its saturation; $m-$ is the time of one extraction cycle; $x-$ is the extraction time; $y-$ is the concentration of biologically active substances in the extractant.

Tan and Liou [6] proposed a one-parameter model describing a desorption of activated carbon loaded with toluene by supercritical fluid extraction.

In the work [7], theoretical models of diffusion of a hot ball, damaged and undamaged cells, shrinkage core and other relatively simple models are reviewed. Modeling process parameters include average particle size, solvent flow rate, pressure, temperature, and modifier concentration and their effect on mass transfer coefficients.

The mechanisms involved in the mass transfer model are described in terms of resistance to external and internal mass transfer, the interaction of a dissolved substance and a solid body, and axial dispersion. Based on the studies carried out, the model of a damaged and undamaged cell has been determined to be suitable. It can be used to simulate supercritical fluid extraction as it reflects the solid structure and kinetics of the extraction process and allows scale up of laboratory data for industrial design. This is confirmed by work [8] on the example of extraction of lupulon from Humulus seeds by supercritical fluid extraction.

The authors of [9] investigated the yields of essential oil components during supercritical fluid extraction $\left(\mathrm{P}=7-15 \mathrm{MPa}, \mathrm{T}=16-50^{\circ} \mathrm{C}\right)$ on the example of plants of the Apiaceae and Asteraceae families. At the same time, it was determined that the resistance to mass transfer is negligible when extracting the compo- 
nents of essential oils and does not depend on the degree of grinding of the raw materials. It has a significant effect only during the extraction of Piper nigrum L. and Myristica, where the extract yield directly depends on the degree of grinding of the raw materials. Based on experimental data, a mathematical model has been developed that describes the kinetics of extraction and takes into account the structure of plant raw materials.

Models of $\mathrm{CO}_{2}$-extraction of Ocimum basilicum L. were studied by the authors of [10], while the factors influencing the yield of the target substances, pressure and temperature were chosen. Brunner's, Candio's and Spiro's models, Esquivel's empirical model, Gordillo's model and others were considered in the work. It was found that the process of $\mathrm{CO}_{2}$-extraction of Ocimum basilicum $\mathrm{L}$. for the extraction of linalool is most closely described by the Gordillo model, while its solubility is strongly dependent on pressure. At the same time the process of eugenol extraction is described by the Del Vale and Aguilera model, which characterizes the dependence of solubility on temperature.

The kinetics of the extraction process of Satureja montana L. with supercritical carbon dioxide for the quantitative extraction of essential oil components has been studied. Modeling was carried out using the equations of Ficks, Esquivel, Chrastil, Valle and Aquilera, Adachi and Lu, Sparks. It was established that all models have a similar deviation from the experimental data, and the Esquivel model most closely describes the extraction process of Satureja montana L. [11].

Researchers at the Institute of Technology (Brazil) [12] have studied the process of extracting citronella essential oil, which contains more than eighty components. It has been established that the quantitative extraction of the sum of components of the essential oil of Cymbopogon nardus $\mathrm{L}$. is achieved at $18.0 \mathrm{MPa}$ and at of $80{ }^{\circ} \mathrm{C}$ temperature. The Naik and Lentz models were used to calculate the extraction process; they showed good agreement with experimental data.

A mathematical model for the extraction of essential oil by steam distillation, based on Fick's law in a non-stationary state for a one-dimensional geometry of a rectangle, was calculated using the example of extraction of Rosmarinus officinalis L., Ocimum basilicum L. and Lavandula dentata L. [13].

The effective diffusion coefficient (D) is used in the model as an adjustable parameter to predict the experimental yield curves of the essential oil. It was found that the diffusion mathematical model based on mass transfer has good agreement with experimental data.

Modeling of the process of supercritical fluid extraction of Anethum graveolens L. seeds is given in the work [14]. Pressure, temperature and flow rate of $\mathrm{CO}_{2}$-gas are determined as factors influencing the yield of the target substance. Two models were used for modeling. One is based on desorption, the second is based on the classical model of mass transfer proposed by H. Sovová [15]. The calculation results showed that both models are in good agreement with experimental data, but the second model requires more accurate initial calculations [14].

The process of $\mathrm{CO}_{2}$-extraction of Sesamum seeds has been optimized according to the following technological parameters: pressure, temperature, $\mathrm{CO}_{2}$-gas supply rate and raw material grinding. It was established that an increase in the pressure and flow rate of $\mathrm{CO}_{2}$-gas increases the extract yield and shortens the extraction time, an increase in the degree of seed refinement and a decrease in diffusion resistance also increase the yield of extract. Quantitative yield ( $85 \%$ with hexane extraction) is achieved under the following conditions: $35 \mathrm{MPa}$ pressure, $50{ }^{\circ} \mathrm{C}$ temperature, $2 \mathrm{ml} / \mathrm{min} \mathrm{CO}_{2}$-gas supply rate and 300-600 microns particle size. Shrinking cores and undamaged cores mathematical models were used to describe the extraction process. The shrinking cores model is possessed the best convergence to experimental data [16].

Researchers from the Plapiqui University (Argentina) [17] have proposed a new two-dimensional nonstationary mathematical model for the extraction of plant oil from sunflower pellets in an industrial extractor of De Smet type. Extraction from a moving layer of oil material was modeled taking into account the different availability of oil in pellets, counter-flow of porous substance and micelle, diffusion over the entire extraction area, mass transfer between granules and micelles, micelle transfer to percolation areas, loading and drying zones, as well as transient operation of the extractor.

To describe the process of supercritical $\mathrm{CO}_{2}$-extraction of corn oil cake, researchers at the University of Albert (Canada) used the mathematical models of Sovová and the model of Krastil [18]. It has been established that the quantitative extraction of biologically active substances from corn oil cake is achieved at $49 \mathrm{MPa}$ and at $70^{\circ} \mathrm{C}$ temperature; both models have good agreement with experimental data.

The effect of drying conditions on the composition of supercritical extracts obtained from olive leaves was studied [19]. The leaves were dried on a conveyor belt and the effect of air temperature and residence time on the extraction kinetics, overall yield, antioxidant activity, total polyphenols and the chemical composition of the extracts was assessed. It was established that the drying conditions do not affect on the kinetics 
of extraction. In this case, the quantitative yield was achieved at $60^{\circ} \mathrm{C}$ temperature and at 120 minutes as drying time. To describe the process of $\mathrm{CO}_{2}$-extraction of olive leaves, the H. Sovová model was used, which showed good agreement with experimental data.

The H. Sovová model is widely used to optimize the process of extracting biologically active substances from plant raw materials. So its use to describe the extraction of Salvia officinalis L. by the method of supercritical fluid extraction made it possible to calculate the initial coefficients for multifactorial modeling of the process by an artificial neural network [20]. At the same time the model H. Sovová can also be used independently to optimize supercritical fluid extraction of plant raw materials [21-35].

A modeling approach based on thermodynamic and mass transfer phenomena confirms the BrunauerEmmett-Teller adsorption theory, which was used in the study to correlate supercritical fluid extraction data from Eryngium billardieri L.

A response surface methodology based on a central composite design was used to assess the effects of operating conditions such as pressure, temperature, particle size and dynamic time. The quantitative yield of essential oil was $0.8522 \%$ at $30 \mathrm{MPa}$ pressure, $308 \mathrm{~K}$ temperature, $0.75 \mathrm{~mm}$ particle size and 130 minutes as extraction time. The predicted results showed that the response surface method is in satisfactory agreement with the experimental data. To describe the study, a quadratic model was chosen, including linear, interactive and quadratic terms [36].

First proposed by Dankwerts [37], dispersion models have come to be widely used to describe reactors with imperfect flow. The model was built on the basis of a constant linear velocity of the correspondent fluid flows. This problem creates difficulties in formulating and simulating the model when the fluid velocity changes along the flow path. This situation occurs when the reactor has a non-uniform cross-section or the void fraction changes along the flow path, which is very common in modern reactors. It has been noted that most continuous flow reactors operate at approximately constant flow rates. Given this Siripatana et al. [38] simplified the dispersion model by reformulating the model in terms of volumetric flow rate rather than linear velocity. The model was called the "volumetric dispersion model" and was used for counter-current extraction and adsorption in a fixed bed. Previous work has illustrated the simplicity of a volumetric dispersion model in describing the effect of inhomogeneous cross-section and variable steam quality along reactors [39]. Different mathematical models have been used in previous studies of supercritical fluid extraction, but most of them did not take into account the role of axial dispersion [9, 40, 41]. Nevertheless, some researchers have formulated models based on the formulation of Dankwerts [42-47]. Their models mainly focus on a situation where the fluid velocity is constant in the processing unit and it is not easy to extend them to predict the performance of non-uniform flow reactors/extractors. It is desirable to have a supercritical fluid extraction model that can be used to design and analyze non-uniform flow extractors. It is expected that volumetric variance model will simplify and expand design capabilities without unnecessary mathematical complexity [48].

Modeling of thermodynamic phase equilibrium and optimization of supercritical $\mathrm{CO}_{2}$-extraction processes for the concentration of phytosterol and tocopherol from rapeseed oil using the Striek-Vera PengRobins (3) state equation made it possible to increase the yield and quality of target substances. While the average relative deviation of experimental and calculated data is about $1-12 \%$ [49].

$$
\text { objective }=\frac{1}{n} \sum_{i=1}^{n} \frac{a b s\left(P_{i}^{\exp }-P_{i}^{E O S}\right)}{P_{I}^{\exp }}+\frac{F}{n} \sum_{I=1} \frac{a b s\left(y_{i}^{\exp }-y_{i}^{E O S}\right)}{y_{i}^{\exp }},
$$

here $n-$ is the number of data points; $F-$ is a weighting parameter; $P$ - is the pressure (MPa); $y-$ is a gas composition (mole fraction).

The phenomenological model (4) for the supercritical extraction of alkaloids nicotine and solanesol showed that for the quantitative extraction of target substances, their solubility must be taken into account. This is in good agreement with experimental data showing that a lower pressure is required for the extraction of solanesol (15 MPa) than for nicotine (37 MPa) [50].

$$
\mathrm{K} . \mathrm{a}=\frac{k_{S C F} * a_{S C F} *\left(\frac{F}{1+e^{-\left(t-t_{C_{1}}\right)}}\right)}{1+e^{\left(t-t_{C_{2}}\right)}}+\frac{k_{S} * a_{S}}{1+e^{\left(t-t_{C_{2}}\right)}},
$$

here $k_{S C F}{ }^{*} a_{S C F}$ - is the external mass transfer; $k_{S}{ }^{*} a_{S}$ - is the internal mass transfer; factor $F$ characterizes intermediate stage global extraction process. 


\section{Conclusions}

Thus, the carried out analysis shows that for the transition from laboratory conditions to large-scale production, it is relevant to develop models that directly take into account the parameters of the extraction process, such as pressure, temperature and extraction duration, individual characteristics of raw materials and technological equipment. An empirical approach prevails or simplified differential equations of material balance are used to describe the kinetics of the plant raw materials extraction process. In this case, the H. Sovová mass transfer model and the damaged and undamaged cell model are considered to be relatively adequate models.

The work was carried out under the grant project AP08052030 "Modeling and optimization of the technology of original drugs" funded by the Science Committee of the Ministry of Education and Science of the Republic of Kazakhstan.

\section{References}

1 Grosso C. Mathematical modelling of supercritical $\mathrm{CO}_{2}$ extraction of volatile oils from aromatic plants / C. Grosso, J.P. Coelho, F.L.P. Pesso, J.M.N.A. Fareleira, J.G. Barroso, J.S. Urieta, A.F. Palavra, H. Sovová // Chem. Eng. Sci. — 2010. Vol. 65. - P. 3579-3590. https://doi.org/10.1016/j.ces.2010.02.046

2 Rai A. Evaluation of models for supercritical fluid extraction / A. Rai, K.D. Punase, B. Mohanty, R. Bhargava // Int. J. Heat Mass Transf. — 2014. — Vol. 72. — P. 274-287. https://doi.org/10.1016/j.ijheatmasstransfer.2014.01.011

3 Özkal S. Mass transfer modeling of apricot kernel oil extraction with supercritical carbon dioxide / S. Özkal, M. Yener, L. Bayındırlı // J. Supercrit. Fluids. — 2005. — Vol. 35. — P. 119-127. https://doi.org/10.1016/j.supflu.2004.12.011

4 Максудов Р.Н. Моделирование процесса сверхкритической экстракции из полидисперсного слоя семян масличных культур / Р.Н. Максудов, А.В. Аляев, А.Г. Егоров, А.Б. Мазо // Вестн. Казан. технол. ун-та. — 2011. — № 20. — С. $200-204$.

5 Букин А.А. Математическая модель массопереноса при многоступенчатой экстракции из растительного сырья сжиженным диоксидом углерода / А.А. Букин, П.С. Беляев, В.Г. Однолько, Л.И. Ткач, С.А. Щербаков // Изв. высш. учеб. завед. Пищ. технол. - 2011. - Т. 320, 321, № 2, 3. - С. 69-71.

6 Tan C.-S. Modeling of desorption at supercritical conditions / C.-S. Tan, D.-C. Liou // AIChE Journal. - 1989. Vol. 35(6). - P. 1029-1031. doi:10.1002/aic.690350616

7 Huang Z. Theoretical models for supercritical fluid extraction / Z. Huang, X. Shi, W. Jiang // J. Chromatogr. A. — 2012. Vol. 1250. - P. 2-26. https://doi.org/10.1016/j.chroma.2012.04.032

8 Kupski S.C. Mathematical modeling of supercritical $\mathrm{CO}_{2}$-extraction of hops (Humulus lupulus L.) / S.C. Kupski, E.J. Klein, E.A. Silva, F. Palú, R. Guirardello, M. Gurgel, A. Vieira // J. Supercrit. Fluids. - 2017. - Vol. 130. - P. 347-356. http://dx.doi.org/10.1016/j.supflu.2017.06.011

9 Sovová H. Modeling the supercritical fluid extraction of essential oils from plant materials / H. Sovová // J. Chromatogr. A. — 2012. — Vol. 1250. — P. 27-33. https://doi.org/10.1016/j.chroma.2012.05.014

10 Zekovic Z. Mathematical Modeling of Ocimum basilicum L. Supercritical $\mathrm{CO}_{2}$-Extraction / Z. Zeković, S. Filip, S. Vidović, S. Jokić, S. Svilović // Chem. Eng. Technol. — 2014. — Vol. 37. — P. 1-7. https://doi.org/10.1002/ceat.201400322

11 Vladic J. Winter savory: supercritical carbon dioxide extraction and mathematical modeling of extraction process / J. Vladić, Z. Zeković, S. Jokić, S. Svilović, S. Kovačević, S. Vidović // J. Supercrit. Fluids. - 2016. — Vol. 117. - P. 89-97. http://dx.doi.org/10.1016/j.supflu.2016.05.027

12 Silva C.F. Extraction of citronella (Cymbopogon nardus) essential oil using supercritical $\mathrm{CO}_{2}$ : experimental data and mathematical modeling / C.F. Silva, F.C. Moura, M.F. Mendes, F.L.P. Pessoa // Brazilian J. Chem. Eng. — 2011. - Vol. 28. - P. 343350. http://dx.doi.org/10.1590/S0104-66322011000200019

13 Cassel E. Steam distillation modeling for essential oil extraction process / E. Cassel, R.M.F. Vargas, N. Martinez, D. Lorenzo, E. Dellacassa // Industrial crops and products. — 2009. - Vol. 29. — P. 171-176. https://doi.org/10.1016/j.indcrop. 2008.04.017

14 Garcez J.J. Evaluation and mathematical modeling of processing variables for asupercritical fluid extraction of aromatic compounds from Anethum graveolens / J.J. Garcez, F. Barros, A.M. Lucas, V.B. Xavier, A.L. Fianco, E. Cassel, R.M.F. Vargas // Industrial Crops and Products. — 2017. — Vol. 95. — P. 733-741. https://doi.org/10.1016/j.indcrop.2016.11.042

15 Sovová $\mathrm{H}$. Rate of the vegetable oil extraction with supercritical $\mathrm{CO}_{2}-\mathrm{I}$. Modeling of extraction curves / H. Sovová // Chem. Eng. Sci. — 1994. — Vol. 49. — P. 409-414. https://doi.org/10.1016/0009-2509(94)87012-8

16 Döker O. Extraction of sesame seed oil using supercritical $\mathrm{CO}_{2}$ and mathematical modeling / O. Döker, U. Salgin, N. Yildiz, M. Aydoğmuş, A. Çalimli // Journal of Food Engineering. — 2010. — Vol. 97. — P. 360-366. https://doi.org/10.1016/j.jfoodeng. 2009.10.030

17 Carrın M.E. Mathematical modeling of vegetable oil-solvent extraction in a multistage horizontal extractor / M.E. Carrin, G.H. Crapiste // Journal of Food Engineering. — 2008. — Vol. 85. — P. 418-425. https://doi.org/10.1016/j.jfoodeng.2007.08.003 
18 Ciftci O.N. Supercritical Carbon Dioxide Extraction of Corn Distiller's Dried Grains with Solubles: Experiments and Mathematical Modeling / O.N. Ciftci, J. Calderon, F. Temelli // J. Agric. Food Chem. — 2012. — Vol. 60. — P. $12482-12490$. https://doi.org/10.1021/jf302932w

19 Canabarro N.I. Drying of olive (Olea europaea L.) leaves on a conveyor belt for supercritical extraction of bioactive compounds: Mathematical modeling of drying/extraction operations and analysis of extracts / N.I. Canabarro, M.A. Mazutti, M.C. Ferreira // Industrial Crops \& Products. — 2019. — Vol. 136. — P. 140-151. https://doi.org/10.1016/j.indcrop.2019.05.004

20 Pavlić B. Extraction kinetics and ANN simulation of supercritical fluid extraction of sage herbal dust / B. Pavlić, O. Bera, S. Vidović, L. Ilić, Z. Zeković // J. Supercrit. Fluids. — 2017. — Vol. 130. — P. 327-336. https://doi.org/10.1016/j.supflu.2017. 11.006

21 Popa O. Modeling the extraction curve of Amaranth oil with Sovova model / O. Popa, N. Babeanu, S. Nita, D.I. Marin // Journal of Biotechnology. — 2016. — Vol. 231S. — P. S4-S109. http://dx.doi.org/10.1016/j.jbiotec.2016.05.200

22 Braga M.E.M. Mathematical modelling of turmeric compounds extraction using high pressurized solvents mixture / M.E.M. Braga, S. Quispe-Condori, P.T.V. Rosa, M. Angela, A. Meireles // J. Supercrit. Fluids. — 2018. — Vol. 140. — P. $348-355$. https://doi.org/10.1016/j.supflu.2018.07.014

23 Lopes N.L. Evaluation of the effects of pressurized solvents and extraction process parameters on seed oil extraction in Pachira aquatica / N.L. Lopes, J.M.F. Almeida-Couto, C. Silva, M.B. Pereira, T.C. Pimentel, C.E. Barão, L. Cardozo-Filho // J. Supercrit. Fluids. — 2020. — Vol. 161. — P. 104823. https://doi.org/10.1016/j.supflu.2020.104823

24 Confortin T.C. Supercritical $\mathrm{CO}_{2}$ extraction of compounds from different aerial parts of Senecio brasiliensis: Mathematical modeling and effects of parameters on extract quality / T.C. Confortin, I. Todero, N.I. Canabarro, L. Luft, G.A. Ugalde, J.R.C. Neto, et. al. // J. Supercrit. Fluids. — 2019. — Vol. 153. — P. 104589. https://doi.org/10.1016/j.supflu.2019.104589

25 Palsikowski P.A. Supercritical $\mathrm{CO}_{2}$ oil extraction from Bauhinia forficata link subsp. pruinosa leaves: Composition, antioxidant activity and mathematical modeling / P.A. Palsikowski, L.M. Besen, K.A. Santos, C. Silva, E.A. Silva // J. Supercrit. Fluids. 2019. — Vol. 153. — P. 104588. https://doi.org/10.1016/j.supflu.2019.104588

26 Santos K.A. Supercritical $\mathrm{CO}_{2}$ extraction of favela (Cnidoscolus quercifolius) seed oil: Yield, composition, antioxidant activity, and mathematical modeling / K.A. Santos, E.A. Silva, C. Silva // J. Supercrit. Fluids. — 2020. — Vol. 165. — P. 104981. https://doi.org/10.1016/j.supflu.2020.104981

27 Liu X. Ultrasound-assisted supercritical $\mathrm{CO}_{2}$ extraction of cucurbitacin E from Iberis amara seeds / X. Liu, H. Ou, H. Gregersen // Industrial Crops and Products. — 2020. — Vol. 145. — P. 112093. https://doi.org/10.1016/j.indcrop.2020.112093

28 Mouahid A. Supercritical $\mathrm{CO}_{2}$ extraction of oil from Jatropha curcas: An experimental and modelling study / A. Mouahid, H. Bouanga, C. Crampon, E. Badens // J. Supercrit. Fluids. — 2018. — Vol. 141. — P. 2-11. https://doi.org/10.1016/j.supflu. 2017.11.014

29 Hassim N. Scale-up criteria and economic analysis for supercritical fluid extraction of Phyllanthus niruri / N. Hassim, M. Markom, M.I. Rosli, S. Harun // Chemical Engineering \& Processing: Process Intensification. — 2019. — Vol. 139. — P. 14-22. https://doi.org/10.1016/j.cep.2019.03.011

30 Pavlic B. Supercritical fluid extraction of raspberry seed oil: Experiments and modeling / B. Pavlić, L. Pezo, B. Marić, L.P. Tukuljac, Z. Zeković, M.B. Solarov, N. Teslić // J. Supercrit. Fluids. — 2020. — Vol. 157. — P. 104687. https://doi.org/ 10.1016/j.supflu.2019.104687

31 Natolino A. Supercritical carbon dioxide extraction of pomegranate (Punica granatum L.) seed oil: Kinetic modelling and solubility evaluation / A. Natolino, C. Porto // J. Supercrit. Fluids. - 2019. — Vol. 151. — P. 30-39. https://doi.org/10.1016/ j.supflu.2019.05.002

32 Zanqui A.B. Extraction and assessment of oil and bioactive compounds from cashew nut (Anacardium occidentale) using pressurized n-propane and ethanol as cosolvent / A.B. Zanqui, C.M. Silva, J.B. Ressutte, D.R. Morais, J.M. Santos, M.N. Eberlin, et. al. // J. Supercrit. Fluids. — 2020. — Vol. 157. — P. 104686. https://doi.org/10.1016/j.supflu.2019.104686

33 Kavoura D. Supercritical $\mathrm{CO}_{2}$ extraction of Salvia fruticosa / D. Kavoura, K. Kyriakopoulou, G. Papaefstathiou, E. Spanidi, K. Gardikis, V. Louli, N. Aligiannis, et. al. // J. Supercrit. Fluids. — 2019. — Vol. 146. — P. 159-164. https://doi.org/10.1016/ j.supflu.2019.01.010

34 Soto-Armenta L.C. Extraction yield and kinetic study of Lippia graveolens with supercritical $\mathrm{CO}_{2} /$ L.C. Soto-Armenta, J.C. Sacramento-Rivero, C.A. Ruiz-Mercado, M.C. Lope-Navarrete, J.A. Rocha-Uribe // J. Supercrit. Fluids. — 2019. — Vol. 145. — P. 205-210. https://doi.org/10.1016/j.supflu.2018.12.018

35 Mouahid A. Effects of high water content and drying pre-treatment on supercritical $\mathrm{CO}_{2}$ extraction from Dunaliella salina microalgae: Experiments and modeling / A. Mouahid, C. Crampon, S.-A.A. Toudji, E. Badens // J. Supercrit. Fluids. — 2016. — Vol. 116. - P. 271-280. https://doi.org/10.1016/j.supflu.2016.06.007

36 Sodeifian G. Experimental optimization and mathematical modeling of the supercritical fluid extraction of essential oil from Eryngium billardieri: Application of simulated annealing (SA) algorithm / G. Sodeifian, S.A. Sajadian, N.S. Ardestani // J. Supercrit. Fluids. — 2017. - Vol. 127. — P. 146-157. https://doi.org/10.1016/j.supflu.2017.04.007

37 Danckwerts P.V. Continuous flow systems: Distribution of residence times / P.V. Danckwerts // Chem. Eng. Sci. - 1953. Vol. 2. - P. 1-13. http://dx.doi.org/10.1016/0009-2509(53)80001-1

38 Siripatana C. Generalized volumetric dispersion model for a class of two-phase separation/reaction: Finite difference solutions / C. Siripatana, H. Thongpan, A.A. Promraksa // J. Phys. Conf. Ser. — 2017. — Vol. 820. — P. 012015. http://dx.doi.org/ $10.1088 / 1742-6596 / 820 / 1 / 012015$ 
39 Huang Z. Theoretical models for supercritical fluid extraction / Z. Huang, X. Shi, W. Jiang // J. Chromatogr. A. — 2012. Vol. 1250. — P. 2-26. http://dx.doi.org/10.1016/j.chroma.2012.04.032

40 Salamatin A.A. Optimization of supercritical fluid extraction: Polydisperse packed beds and variable flow rates / A.A. Salamatin, A.G. Egorov // J. Supercrit. Fluids. — 2015. — Vol. 105. — P. 35-43. http://dx.doi.org/10.1016/j.supflu.2015.01.013

41 Duba K.S. Supercritical extraction of vegetable oils: Different approaches to modeling the mass transfer kinetics / K.S. Duba, L. Fiori // Chem. Eng. Trans. — 2015. — Vol. 43. — P. 1051-1056. http://dx.doi.org/10.3303/CET1543176

42 Goto M. Shrinking-core leaching model for supercritical-fluid extraction / M. Goto, B.C. Roy, T. Hirose // J. Supercrit. Fluids. - 1996. - Vol. 9. - P. 128-133. http://dx.doi.org/10.1016/S0896-8446(96)90009-1

43 Honarvar B. Mathematical modeling of supercritical fluid extraction of oil from canola and sesame seeds / B. Honarvar, S.A. Sajadian, M. Khorram, A. Samimi // Braz. J. Chem. Eng. — 2013. — Vol. 30. — P. 159-166. http://dx.doi.org/10.1590/S010466322013000100018

44 Stamenic M. The mathematics of modelling the supercritical fluid extraction of essential oils from glandular trichomes / M. Stamenic, I. Zizovic // Comput. Chem. Eng. - 2013. - Vol. 48. - P. 89-95. http://dx.doi.org/10.1016/j.compchemeng. 2012.08.006

45 Rai A. Evaluation of models for supercritical fluid extraction / A. Rai, K.D. Punase, B. Mohanty, R. Bhargava // Int. J. Heat Mass Tran. - 2014. - Vol. 72. — P. 274-287. http://dx.doi.org/10.1016/j.ijheatmasstransfer.2014.01.011

46 Pereira T.J.G. Mathematical modeling of supercritical extraction: Model of two phases with linear equilibrium /

T.J.G. Pereira, L.F.G. Machado, J.L. Ferreira, E.N. Macêdo // Int. J. Model. Simul. Petrol. Ind. — 2014. — Vol. 8. — P. 9-17.

47 Song Y. Kinetics model for supercritical fluid extraction with variable mass transport / Y. Song, L. Zheng, X. Zhang // Int. J. Heat Mass Tran. — 2017. — Vol. 122. — P. 876-881. http://dx.doi.org/10.1016/j.ijheatmasstransfer.2017.05.002

48 Promraksa A. Modeling of Supercritical $\mathrm{CO}_{2}$ Extraction of Palm Oil and Tocopherols Based on Volumetric Axial Dispersion / A. Promraksa, C. Siripatana, N. Rakmak, N. Chusri // J. Supercrit. Fluids. - 2020. — Vol. 166. - P. 105021. https://doi.org/ 10.1016/j.supflu.2020.105021

49 Jafarian A.P. Modelling and simulation of supercritical $\mathrm{CO}_{2}$-extraction of bioactive compounds from vegetable oil waste / A.P. Jafarian, R. Niazmand // Food and Bioproducts Processing. — 2020. — Vol. 122. — P. 311-321. https://doi.org/10.1016/ j.fbp.2020.05.005

50 Tita G.J. Model assisted supercritical fluid extraction and fractionation of added-value products from tobacco scrap / G.J. Tita, A. Navarrete, Á. Martín, M.J. Cocero // J. Supercrit. Fluids. — 2021. — Vol. 167. — P. 105046. https://doi.org/10.1016/ j.supflu.2020.105046

\title{
И.А. Хабаров, В.В. Журов, А.Н. Жабаева, С.М. Адекенов
}

\section{Дәрілік шикізатты экстракциялау үдерісін модельдеу}

\begin{abstract}
Мақалада дәрілік өсімдік шикізатынан биологиялық белсенді компоненттерді экстракциялау үдерісінің 26 математикалық моделі қарастырылған, олар шығарып алу үдерісіне әсер ететін факторларды ескереді: диффузия коэффициенті, бөлшектердің мөлшері, қабаттың кеуектігі, экстрагент беру жылдамдығы, шикізатты ұсату тәсілі, шығарып алу қысымы, температурасы мен ұзақтығы, шикізат (мақсатты компоненттің құрамы) пен технологиялық жабдықтың жеке сипаттамасы. Жалпы алғанда, бұл модельдер төрт маңызды топқа бөлінеді: эмпирикалық модельдер, жылу беру аналогтарына негізделген модельдер, сығылатын ядро модельдері және массаның дифференциалды тепе-теңдігіне негізделген модельдер. Математикалық модельдерді таңдауда ең алдымен, экстракциялық сұйықтықтар ағындарының идеалды емес әрекетімен, экстракциялық аппараттардың біртекті емес көлденең қимасымен байланысты мәселелер сипатталған. Экстракциялау үдерісін модельдеу, ең алдымен, қатты бөлшектердің ішіндегі масса тасымалын сипаттау үшін математикалық модельдерді қажет ететіні көрсетілген. Сондай-ақ, модельдеу кезінде мақсатты заттардың ерігіштігін ескеру қажет. Жүргізілген талдау негізінде өсімдік шикізатынан биологиялық белсенді заттарды экстракциялау үдерістерінің негізгі факторларын есептеу үшін диффузиялық, H. Sovová, Naik және Lentz, Esquivel, бұзылған және зақымдалмаған ұяшық модельдері оңтайлы болып табылатыны анықталды.
\end{abstract}

Кілт сөздер: математикалық модельдеу, масса тасымалдау, диффузия, регрессия теңдеуі, критерийлік теңдеу, оңтайландыру, экстракция, дәрілік шикізат.

\section{И.А. Хабаров, В.В. Журов, А.Н. Жабаева, С.М. Адекенов}

\section{Моделирование процесса экстракции лекарственного сырья}

В обзорной статье рассмотрены 26 математических моделей процесса экстракции биологически активных веществ из лекарственного растительного сырья, учитывающие факторы, влияющие на про- 
цесс извлечения: коэффициент диффузии, размер частиц, пористость слоя, скорость подачи экстрагента, способ измельчения сырья, давление, температуру и продолжительность извлечения, индивидуальную характеристику сырья (содержание целевого компонента) и технологического оборудования. В целом, эти модели делятся на четыре важные группы: эмпирические модели; модели, основанные на аналогиях теплопередачи; модель сжимающегося ядра и модели, основанные на дифференциальном балансе массы. Описаны проблемы при подборе математических моделей, связанных, прежде всего, с неидеальным поведением потоков экстракционных жидкостей, неоднородным поперечным сечением экстракционных аппаратов. Показано, что моделирование процесса экстракции, в первую очередь, требует математических моделей для описания массопереноса внутри твердых частиц. Также при моделировании важно учитывать растворимость целевых веществ. На основании проведенного анализа определено, что для расчета основных факторов экстракционных процессов биологически активных веществ из растительного сырья оптимальными являются модели: диффузионная, H. Sovová, Naik и Lentz, Esquivel, разрушенной и неповрежденной ячейки.

Ключевые слова: математическое моделирование, массоперенос, диффузия, уравнение регрессии, критериальное уравнение, оптимизация, экстракция, растительное сырье.

\section{References}

1 Grosso, C., et. al. (2010). Mathematical modelling of supercritical $\mathrm{CO}_{2}$ extraction of volatile oils from aromatic plants. Chem. Eng. Sci., 65, 3579-3590. https://doi.org/10.1016/j.ces.2010.02.046

2 Rai, A., et al. (2014). Evaluation of models for supercritical fluid extraction. Int. J. Heat Mass Transf., 72, $274-287$. https://doi.org/10.1016/j.ijheatmasstransfer.2014.01.011

3 Özkal, S., Yener, M., \& Bayındırlı, L. (2005). Mass transfer modeling of apricot kernel oil extraction with supercritical carbon dioxide. J. Supercrit. Fluids, 35, 119-127. https://doi.org/10.1016/j.supflu.2004.12.011

4 Maksudov, R.N., et al. (2011). Modelirovanie protsessa sverkhkriticheskoi ekstraktsii iz polidispersnoho sloia semian maslichnykh kultur [Modeling the process of supercritical extraction from a polydisperse layer of oilseeds cultures]. Vestnik Kazanskoho tekhnolohicheskoho universiteta - Bulletin of Kazan Technological University, 20, 200-204 [in Russian].

5 Bukin, A.A., et al. (2011). Matematicheskaia model massoperenosa pri mnohostupenchatoi ekstraktsii iz rastitelnoho syria szhizhennym dioksidom uhleroda [Mathematical model of mass transfer during multistage extraction from plant raw materials with liquefied carbon dioxide]. Izvestiia vysshikh uchebnykh zavedenii. Pishchevaia tekhnolohiia - News of Higher Educational Institutions. Food Technology, 320-321, 2-3, 69-71 [in Russian].

6 Tan, C.-S., \& Liou, D.-C. (1989). Modeling of desorption at supercritical conditions. AIChE Journal, 35(6), $1029-1031$. DOI: $10.1002 /$ aic. 690350616

7 Huang, Z., Shi, X., \& Jiang, W. (2012). Theoretical models for supercritical fluid extraction. J. Chromatogr. A, 1250, 2-26. https://doi.org/10.1016/j.chroma.2012.04.032

8 Kupski, S.C., et al. (2017). Mathematical modeling of supercritical $\mathrm{CO}_{2}$-extraction of hops (Humulus lupulus L.). J. Supercrit. Fluids, 130, 347-356. http://dx.doi.org/10.1016/j.supflu.2017.06.011

9 Sovová, H. (2012). Modeling the supercritical fluid extraction of essential oils from plant materials. J. Chromatog. A, 1250, 27-33. https://doi.org/10.1016/j.chroma.2012.05.014

10 Zekovic, Z., et al. (2014). Mathematical Modeling of Ocimum basilicum L. Supercritical $\mathrm{CO}_{2}$-Extraction. Chem. Eng. Technol., 37, 1-7. https://doi.org/10.1002/ceat.201400322

11 Vladic, J., et al. (2016). Winter savory: supercritical carbon dioxide extraction and mathematical modeling of extraction process. J. Supercrit. Fluids, 117, 89-97. http://dx.doi.org/10.1016/j.supflu.2016.05.027

12 Silva, C.F., et al. (2011). Extraction of citronella (Cymbopogon nardus) essential oil using supercritical $\mathrm{CO}_{2}$ : experimental data and mathematical modeling. Brazilian J. Chem. Eng., 28, 343-350. http://dx.doi.org/10.1590/S0104-66322011000200019

13 Cassel, E., et al. (2009). Steam distillation modeling for essential oil extraction process. Industrial crops and products, 29, 171-176. https://doi.org/10.1016/j.indcrop.2008.04.017

14 Garcez, J.J., et al. (2017). Evaluation and mathematical modeling of processing variables for asupercritical fluid extraction of aromatic compounds from Anethum graveolens. Industrial Crops and Products, 95, 733-741. https://doi.org/10.1016/j.indcrop. 2016.11.042

15 Sovová, H. (1994). Rate of the vegetable oil extraction with supercritical $\mathrm{CO}_{2}-\mathrm{I}$. Modeling of extraction curves. Chem. Eng. Sci., 49, 409-414. https://doi.org/10.1016/0009-2509(94)87012-8

16 Döker, O., et al. (2010). Extraction of sesame seed oil using supercritical $\mathrm{CO}_{2}$ and mathematical modeling. Journal of Food Engineering, 97, 360-366. https://doi.org/10.1016/j.jfoodeng.2009.10.030

17 Carrın, M.E., \& Crapiste, G.H. (2008). Mathematical modeling of vegetable oil-solvent extraction in a multistage horizontal extractor. Journal of Food Engineering, 85, 418-425. https://doi.org/10.1016/j.jfoodeng.2007.08.003

18 Ciftci, O.N., Calderon, J., \& Temelli, F. (2012). Supercritical Carbon Dioxide Extraction of Corn Distiller's Dried Grains with Solubles: Experiments and Mathematical Modeling. J. Agric. Food Chem., 60, 12482-12490. https://doi.org/10.1021/ jf302932w 
19 Canabarro, N.I., Mazutti, M.A., \& Ferreira, M.C. (2019). Drying of olive (Olea europaea L.) leaves on a conveyor belt for supercritical extraction of bioactive compounds: Mathematical modeling of drying/extraction operations and analysis of extracts. Industrial Crops \& Products, 136, 140-151. https://doi.org/10.1016/j.indcrop.2019.05.004

20 Pavlić, B., et al. (2017). Extraction kinetics and ANN simulation of supercritical fluid extraction of sage herbal dust. J. Supercrit. Fluids, 130, 327-336. https://doi.org/10.1016/j.supflu.2017.11.006

21 Popa, O., et al. (2016). Modeling the extraction curve of Amaranth oil with Sovova model. Journal of Biotechnology, 231S, S4-S109. http://dx.doi.org/10.1016/j.jbiotec.2016.05.200

22 Braga, M.E.M., et al. (2018). Mathematical modelling of turmeric compounds extraction using high pressurized solvents mixture. J. Supercrit. Fluids, 140, 348-355. https://doi.org/10.1016/j.supflu.2018.07.014

23 Lopes, N.L., et al. (2020). Evaluation of the effects of pressurized solvents and extraction process parameters on seed oil extraction in Pachira aquatica. J. Supercrit. Fluids, 161, 104823. https://doi.org/10.1016/j.supflu.2020.104823

24 Confortin, T.C., et al. (2019). Supercritical $\mathrm{CO}_{2}$ extraction of compounds from different aerial parts of Senecio brasiliensis: Mathematical modeling and effects of parameters on extract quality. J. Supercrit. Fluids, 153, 104589. https://doi.org/10.1016/ j.supflu.2019.104589

25 Palsikowski, P.A., et al. (2019). Supercritical $\mathrm{CO}_{2}$ oil extraction from Bauhinia forficata link subsp. pruinosa leaves: Composition, antioxidant activity and mathematical modeling. J. Supercrit. Fluids, 153, 104588. https://doi.org/10.1016/ j.supflu.2019.104588

26 Santos, K.A., Silva, E.A., \& Silva, C. (2020). Supercritical $\mathrm{CO}_{2}$ extraction of favela (Cnidoscolus quercifolius) seed oil: Yield, composition, antioxidant activity, and mathematical modeling. J. Supercrit. Fluids, $165,104981$. https://doi.org/10.1016/j.supflu.2020.104981

27 Liu, X., Ou, H., \& Gregersen, H. (2020). Ultrasound-assisted supercritical $\mathrm{CO}_{2}$ extraction of cucurbitacin E from Iberis amara seeds. Industrial Crops and Products, 145, 112093. https://doi.org/10.1016/j.indcrop.2020.112093

28 Mouahid, A., et al. (2018). Supercritical $\mathrm{CO}_{2}$ extraction of oil from Jatropha curcas: An experimental and modelling study. J. Supercrit. Fluids, 141, 2-11. https://doi.org/10.1016/j.supflu.2017.11.014

29 Hassim, N., et al. (2019). Scale-up criteria and economic analysis for supercritical fluid extraction of Phyllanthus niruri. Chemical Engineering \& Processing: Process Intensification, 139, 14-22. https://doi.org/10.1016/j.cep.2019.03.011

30 Pavlic, B., et al. (2020). Supercritical fluid extraction of raspberry seed oil: Experiments and modeling. J. Supercrit. Fluids, 157, 104687. https://doi.org/10.1016/j.supflu.2019.104687

31 Natolino, A., \& Porto, C. (2019). Supercritical carbon dioxide extraction of pomegranate (Punica granatum L.) seed oil: Kinetic modelling and solubility evaluation. J. Supercrit. Fluids, 151, 30-39. https://doi.org/10.1016/j.supflu.2019.05.002

32 Zanqui, A.B., et al. (2020). Extraction and assessment of oil and bioactive compounds from cashew nut (Anacardium occidentale) using pressurized n-propane and ethanol as cosolvent. J. Supercrit. Fluids, 157, 104686. https://doi.org/10.1016/ j.supflu.2019.104686

33 Kavoura, D., et al. (2019). Supercritical $\mathrm{CO}_{2}$ extraction of Salvia fruticosa. J. Supercrit. Fluids, 146, $159-164$. https://doi.org/10.1016/j.supflu.2019.01.010

34 Soto-Armenta, L.C., et al. (2019). Extraction yield and kinetic study of Lippia graveolens with supercritical $\mathrm{CO}_{2}$. J. Supercrit. Fluids, 145, 205-210. https://doi.org/10.1016/j.supflu.2018.12.018

35 Mouahid, A., et al. (2016). Effects of high water content and drying pre-treatment on supercritical $\mathrm{CO}_{2}$ extraction from Dunaliella salina microalgae: Experiments and modeling. J. Supercrit. Fluids, 116, 271-280. https://doi.org/10.1016/j.supflu. 2016.06.007

36 Sodeifian, G., Sajadian, S.A., \& Ardestani, N.S. (2017). Experimental optimization and mathematical modeling of the supercritical fluid extraction of essential oil from Eryngium billardieri: Application of simulated annealing (SA) algorithm. J. Supercrit. Fluids, 127, 146-157. https://doi.org/10.1016/j.supflu.2017.04.007

37 Danckwerts, P.V. (1953). Continuous flow systems: Distribution of residence times. Chem. Eng. Sci., 2, 1-13. http://dx.doi.org/10.1016/0009-2509(53)80001-1

38 Siripatana, C., Thongpan, H., \& Promraksa, A.A. (2017). Generalized volumetric dispersion model for a class of two-phase separation/reaction: Finite difference solutions. J. Phys. Conf. Ser., 820, 012015. http://dx.doi.org/10.1088/1742-6596/820/1/012015

39 Huang, Z., Shi, X., \& Jiang, W. (2012). Theoretical models for supercritical fluid extraction. J. Chromatogr. A., $1250,2-26$. http://dx.doi.org/10.1016/j.chroma.2012.04.032

40 Salamatin, A.A., \& Egorov, A.G. (2015). Optimization of supercritical fluid extraction: Polydisperse packed beds and variable flow rates. J. Supercrit. Fluids, 105, 35-43. http://dx.doi.org/10.1016/j.supflu.2015.01.013

41 Duba, K.S., \& Fiori, L. (2015). Supercritical extraction of vegetable oils: Different approaches to modeling the mass transfer kinetics. Chem. Eng. Trans., 43, 1051-1056. http://dx.doi.org/10.3303/CET1543176

42 Goto, M., Roy, B.C., \& Hirose, T. (1996). Shrinking-core leaching model for supercritical-fluid extraction. J. Supercrit. Fluids, 9, 128-133. http://dx.doi.org/10.1016/S0896-8446(96)90009-1

43 Honarvar, B., et al. (2013). Mathematical modeling of supercritical fluid extraction of oil from canola and sesame seeds. Braz. J. Chem. Eng., 30, 159-166. http://dx.doi.org/10.1590/S0104-66322013000100018

44 Stamenic, M., \& Zizovic, I. (2013). The mathematics of modelling the supercritical fluid extraction of essential oils from glandular trichomes. Comput. Chem. Eng., 48, 89-95. http://dx.doi.org/10.1016/j.compchemeng.2012.08.006 
45 Rai, A., et al. (2014). Evaluation of models for supercritical fluid extraction. Int. J. Heat Mass Tran., 72, 274-287., http://dx.doi.org/10.1016/j.ijheatmasstransfer.2014.01.011

46 Pereira, T.J.G., et al. (2014). Mathematical modeling of supercritical extraction: Model of two phases with linear equilibrium. Int. J. Model. Simul. Petrol. Ind., 8, 9-17.

47 Song, Y., Zheng, L., \& Zhang, X. (2017). Kinetics model for supercritical fluid extraction with variable mass transport. Int. J. Heat Mass Tran., 122, 876-881. http://dx.doi.org/10.1016/j.ijheatmasstransfer.2017.05.002

48 Promraksa, A., et al. (2020). Modeling of Supercritical $\mathrm{CO}_{2}$ Extraction of Palm Oil and Tocopherols Based on Volumetric Axial Dispersion. J. Supercrit. Fluids, 166, 105021. https://doi.org/10.1016/j.supflu.2020.105021

49 Jafarian, A.P., \& Niazmand, R. (2020). Modelling and simulation of supercritical $\mathrm{CO}_{2}$-extraction of bioactive compounds from vegetable oil waste. Food and Bioproducts Processing, 122, 311-321. https://doi.org/10.1016/j.fbp.2020.05.005

50 Tita, G.J., et al. (2021). Model assisted supercritical fluid extraction and fractionation of added-value products from tobacco scrap. J. Supercrit. Fluids, 167, 105046. https://doi.org/10.1016/j.supflu.2020.105046

\section{Information about authors}

Khabarov, Iliya Anatolievich - Candidate of Pharmaceutical Sciences, Head of Laboratory, JSC "International Research and Production Holding "Phytochemistry", Gazaliev str. 4, 100009, Karaganda, Kazakhstan, e-mail: i.khabarov@phyto.kz; http://orcid.org/0000-0002-6727-8870.

Zhurov, Vitaliy Vladimirovich - Candidate of Technical Sciences, Researcher, JSC "International Research and Production Holding "Phytochemistry", Gazaliev str. 4, 100009, Karaganda, Kazakhstan, e-mail: zhurvitv@yandex.ru; http://orcid.org/0000-0002-4413-8584.

Zhabayeva, Anar Nikhanbaevna - Candidate of Pharmaceutical Schiences, Chief Technologist, JSC "International Research and Production Holding "Phytochemistry", Gazaliev str. 4, 100009, Karaganda, Kazakhstan, e-mail: a.zhabaeva@phyto.kz; https://orcid.org/0000-0002-9948-7140.

Adekenov, Sergazy Mynzhasarovich - Doctor of Chemical Sciences, General Director, JSC "International Research and Production Holding "Phytochemistry", Gazaliev str. 4, 100009, Karaganda, Kazakhstan, e-mail: arglabin@phyto.kz; https://orcid.org/0000-0001-7588-6174. 